\title{
Hematodinium sp. in Irish Cancer pagurus fisheries: infection intensity as a potential fisheries management tool
}

\author{
C. Ní Chualáin*, M. Hayes, B. Allen, M. Robinson \\ Applied Research Enhancement (ARE) Programme, Shelltec Applied Research Centre, Galway-Mayo Institute of Technology, \\ Dublin Road, Galway, Ireland
}

\begin{abstract}
Infection of Cancer pagurus by a parasitic dinoflagellate of the genus Hematodinium is described for the first time in Ireland. An industry-based monitoring programme was established to determine seasonality of infection intensity and prevalence in the country's 3 largest brown crab fisheries in the southwest, north and southeast. The parasite was present in all areas for the majority of sampling periods, with highest prevalences recorded in pre-recruit animals of both sexes. Microscopic examination of haemolymph revealed trophont, plasmodial and dinospore stages of the parasite. Overall prevalence in males $(16 \%)$ was higher than in females $(9 \%)$. Prevalence of Hematodinium sp. infection ranged from 0 to $51 \%$, but a distinct seasonal trend was not apparent. Infection intensity was seasonal with significantly higher peaks occurring in late autumn/early winter months than in other quarters, corresponding to industry reports of moribund and dead pink-shelled crabs in commercial catches. We postulate that seawater temperature or a temperature-linked process is a key factor in triggering the final stages of infection, as significant autumn peaks were followed by a reduction in infection intensity as temperature decreased in the late winter/early spring months with no increase in intensity again until the following autumn. We propose that infection intensity, rather than prevalence, provides a more appropriate indication of the period when there is greatest potential for biological and economic impacts; the parameter's application as a fisheries management tool is discussed.
\end{abstract}

KEY WORDS: Cancer pagurus · Hematodinium sp. - Infection intensity · Fisheries management . Seasonal temperature

\section{INTRODUCTION}

Parasitic dinoflagellates of the genus Hematodinium have been shown to have negative impacts on a number of commercial crustacean fisheries worldwide (reviewed in Stentiford \& Shields 2005). Pink crab disease (PCD) is a condition associated with infections of Hematodinium sp. in the brown crab Cancer pagurus (Latrouite et al. 1988, Stentiford et al. 2002). Glycogen depletion in severe infections is thought to cause the pinkish lightening in the appearance of the shell (Stentiford \& Shields 2005) and is accompanied by progressive degradation of internal tissues eventually leading to host death (Latrouite et al. 1988, Stentiford et al. 2002). In other host species such as Tanner crabs Chionoecetes bairdi and snow crabs Chionoecetes opilio, meat develops a chalky, unpalatable texture giving rise to the term 'bitter crab disease' (Meyers et al. 1987, 1990, Taylor \& Khan 1995). Data from France (Latrouite et al. 1988) and Ireland (M. Robinson unpubl. data) also suggest that the visual signs of tissue degradation observed in pink-shelled, infected brown crabs are associated with a negative alteration in texture and taste. There is currently concern as to the impacts Hematodinium sp. may have on stock health in Ireland and on consumer confidence, as it is unknown at what stage pathological alterations occur in tissues that are destined for human consumption. 
Shell discolouration, tissue degradation and altered taste can all result in consumer dissatisfaction and reduced product value.

The majority of pot fishing vessels in Ireland are partially or fully reliant on income generated from landing brown crab Cancer pagurus. Economic viability of the Irish offshore vivier fleet is entirely dependent on its ability to exploit the species year-round. The majority of landings are exported live to continental European markets. Approximately $9000 \mathrm{t}$ of brown crabs were landed in Ireland in 2006 with a first sale value estimated at $€ 10$ million (Tully et al. 2006). Hematodinium sp. infections in Irish brown crab fisheries were first confirmed in 2004 (Tully et al. 2006). Reports of the occurrence of pink, dead crabs in fishing pots in the south were similar to those attributed to Hematodinium sp. infections by Latrouite et al. (1988) and Stentiford et al. (2002) previously. An industry-focused monitoring programme was established in Ireland to gauge infection prevalence and seasonality with the aim of developing management measures to limit the biological and economic impact of disease outbreaks. The present study presents data from this programme and discusses findings in relation to disease monitoring and management.

\section{MATERIALS AND METHODS}

Seasonal samples were obtained from 3 geographic locations that together yield $>95 \%$ of annual national landings for Cancer pagurus (Tully et al. 2006). Crabs were captured in baited pots during commercial fishing activity in the north $\left(51^{\circ} 26^{\prime} 25^{\prime \prime} \mathrm{N}, 7^{\circ} 19^{\prime} 33^{\prime \prime} \mathrm{W}\right)$, southwest $\left(51^{\circ} 35^{\prime} 01^{\prime \prime} \mathrm{N}, 10^{\circ} 11^{\prime} 28^{\prime \prime} \mathrm{W}\right)$ and southeast $\left(52^{\circ} 08^{\prime} 34^{\prime \prime} \mathrm{N}, 6^{\circ} 52^{\prime} 01^{\prime \prime} \mathrm{W}\right)$ of Ireland from November 2004 to December 2007. Sex, carapace width (CW) and macroscopic signs of PCD (moribund, pink hyperpigmented carapace, milky coloured haemolymph) were noted. Commercial fishers were requested to bring in crabs from a sample of initial catch prior to grading so that both marketable and unmarketable crabs were sampled (see Table 1 for numbers of crabs). The latter group included sub-legal minimum landing size (<130 mm CW), soft-shelled and damaged crabs. Adherence to this request was verified periodically by onboard observers. Fishermen were asked to report the occurrence of pink crabs in catches at times when sampling was not taking place.

All crabs were collected from baited pots by the fishermen. A sample of the fishermen's catch prior to grading was brought ashore and from these we extracted haemolymph. The number of crabs examined on each sampling occasion can be seen in Table 1. Haemolymph was extracted aseptically from the arthrodial membrane at the juncture of the basis and ischium of one of the walking legs of Cancer pagurus while onboard ship or onshore immediately after landing to port. Samples were immediately fixed in chilled $4 \%$ neutrally buffered formalsaline. Fixed, dry haemolymph smears were stained with Giemsa (Humason 1979) and read without reference to field sampling data. Presence of amoeboid trophonts, plasmodia or dinospores led to a specimen being defined as positive for infection. Identification of the different forms of the parasite (i.e. trophonts, plasmodia or dinospores) was based principally on the descriptions made by Appleton \& Vickerman (1998) with cross-reference to Latrouite et al. (1988) and Stentiford et al. (2002).

For each sampling occasion, infection prevalence was expressed as a percentage by dividing the number of crabs infected with Hematodinium sp. by the number of crabs examined (Bush et al. 1997). As it was not feasible to count all parasites within a host, infection intensity was defined as the percentage of Hematodinium sp. cells counted among haemocytes in a total of 300 cells in randomly selected fields of view. Infection intensities were calculated for all forms of the parasite observed. Mean intensity for a sampling period was the sum of the intensities of infected crabs divided by the number of infected crabs (Sheppard et al. 2003). Mean percentages of plasmodia in infected smears were compared with mean monthly seawater temperatures provided by the Irish Marine Institute from data buoys near each of the 3 sampling areas. Monthly mean infection intensities recorded from sampling points in each quarter of the year (Q1: January to April; Q2: May to June; Q3: July to September; Q4: October to December) were plotted against the same temperature data.

\section{RESULTS}

From November 2004 until December 2007, haemolymph of 4422 Cancer pagurus was examined for Hematodinium sp. infections. Samples comprised 1424,1714 and 1284 crabs from the southwest, north and southeast of Ireland, respectively. Size distribution ranged between $75 \mathrm{~mm}$ to $219 \mathrm{~mm} \mathrm{CW}$ (Fig. 1). Although the size distributions of males and females sampled in each location were not significantly different, a female:male sex ratio of 3:1 was observed, this being representative of commercial catches in Ireland (Tully et al. 2006). Hematodinium sp. infections were confirmed microscopically in crabs from all 3 locations (Fig. 1), but $<1 \%$ of individuals in the present study showed external signs of PCD. When samples from all areas were pooled, the highest infection prevalence was apparent in small size classes for both sexes and 

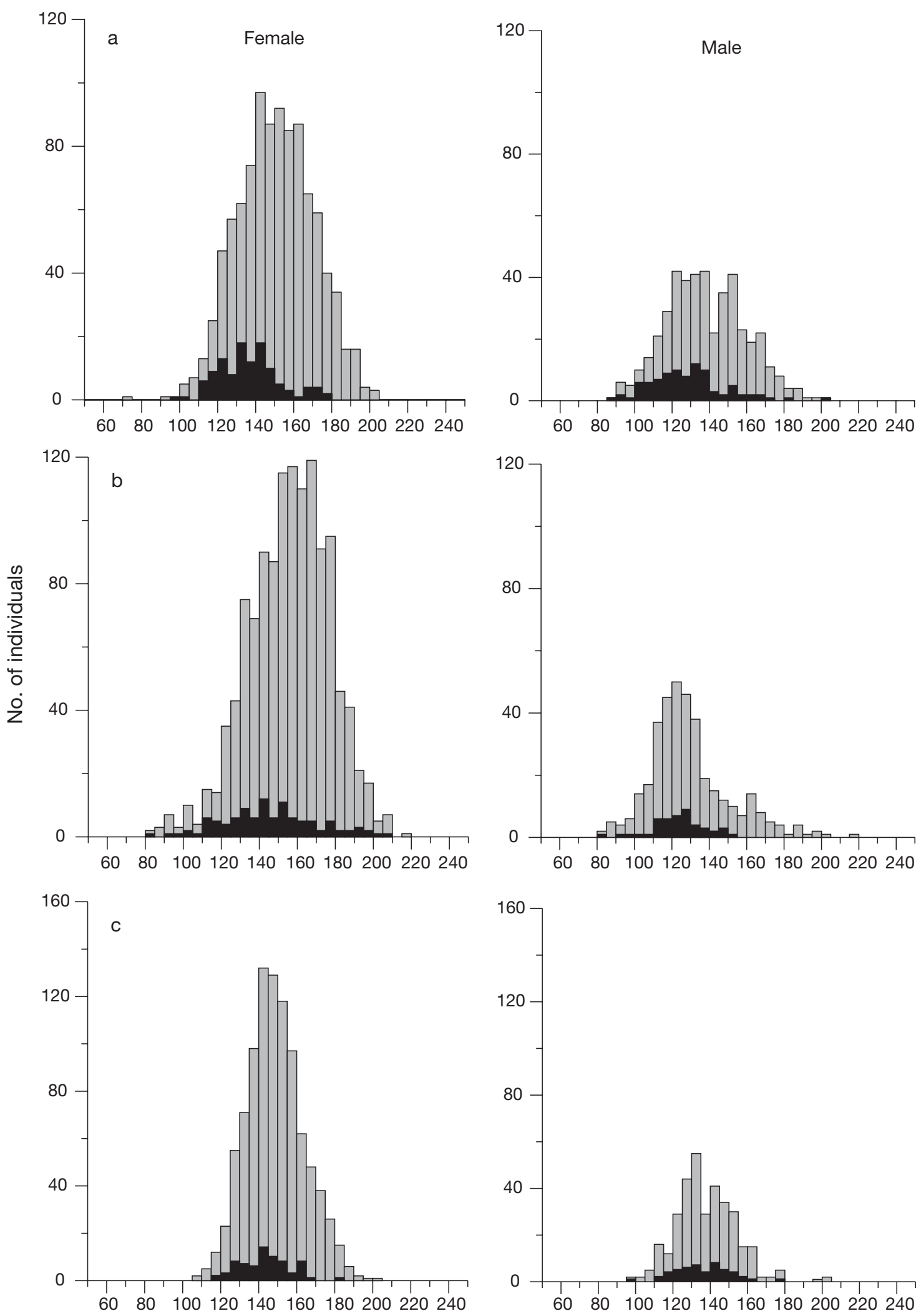

Carapace width $(\mathrm{mm})$

Fig. 1. Cancer pagurus. Sex-specific size-frequency distribution of Hematodinium sp-infected (black bars) and non-infected (grey bars) brown crab from (a) southwest, (b) north and (c) southeast Ireland. Note scale change on $y$-axis of (c) 


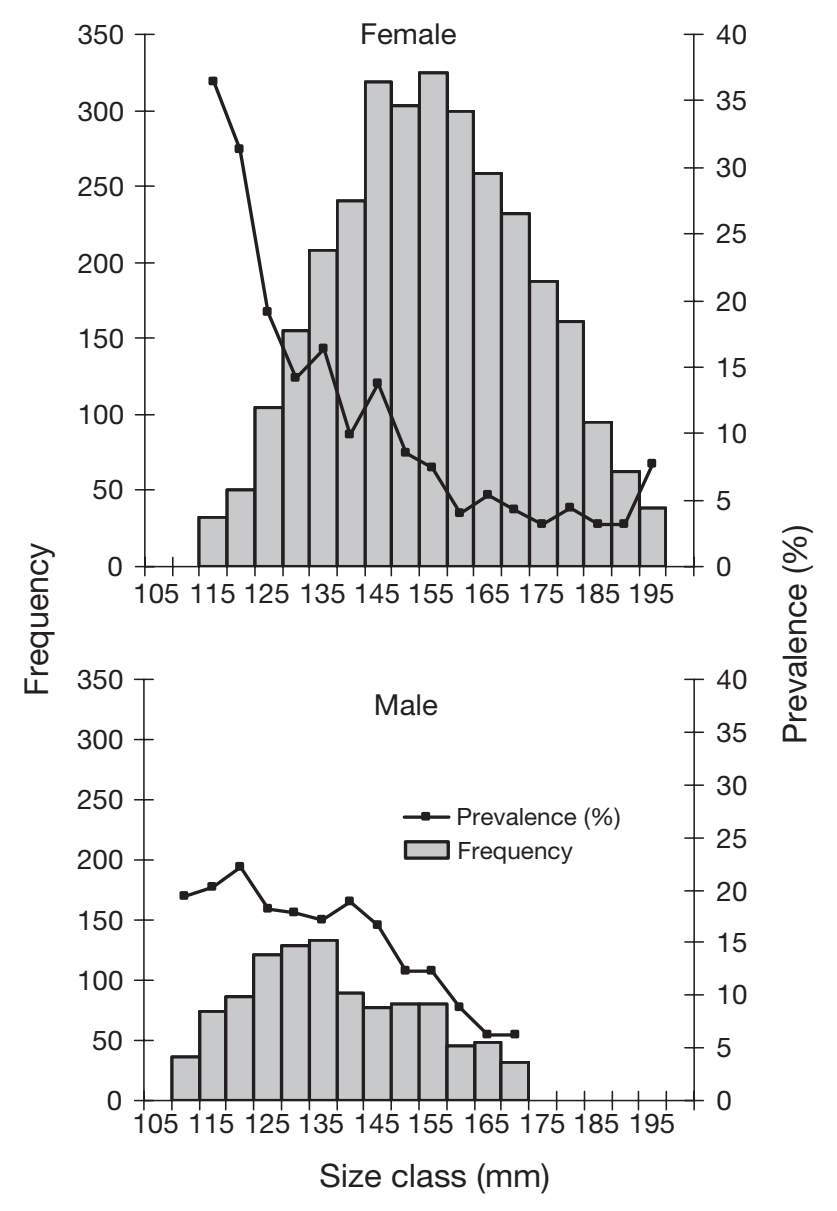

Fig. 2. Cancer pagurus. Sex-specific size-frequency distribution and prevalence of Hematodinium sp. infection for all locations pooled. Only size classes containing $>30$ ind. are included

decreased gradually with increasing size (Fig. 2). Overall, 9 and $16 \%$ of females and males, respectively, were infected when samples were pooled (Table 1). Trophonts were spherical and had a high nuclear cytoplasmic ratio; chromatin varied between uncondensed and distinctly condensed. Plasmodia contained 2 or more nuclei with chromatin often distinctly condensed, appearing in round clump forms. Most positive infections were characterised by trophonts with the host appearing healthy when examined externally. When clinical signs of infection were observed, plasmodia were extremely numerous within the haemolymph. Pyriform dinospores were observed in 1 ind. in each of December 2006 and 2007. Industry reports of dead or dying pink-shelled crabs in fishing pots were received between November and December from the southwest in 2004 to 2007, the north in 2005 to 2007 and the southeast in 2006.

Infection prevalence ranged from 0 to $51 \%, 0$ to $24 \%$, and 0 to $19 \%$ for the southwest, north and southeast, re- spectively (Fig. 3). The southwest experienced the highest prevalence in 2005, reaching $51 \%$ in the winter, over twice that of the north $(23 \%)$ and $>4$ times that of the southeast ( $12 \%$ ) for the same period (Table 1 ). In 2006 , prevalence peaked at $15 \%$ in the southeast, $13 \%$

Table 1. Cancer pagurus. Sex-specific prevalence of Hematodinium sp. infection from 3 regions in Ireland. -: \% infected could not be calculated due to zero value of sample

\begin{tabular}{|c|c|c|c|c|c|c|}
\hline \multirow[t]{2}{*}{ Date } & \multicolumn{2}{|c|}{ — Females — } & \multicolumn{2}{|c|}{ — Males _ـ } & \multicolumn{2}{|c|}{ — Total _ } \\
\hline & $\begin{array}{c}\text { Total } \\
\text { no. }\end{array}$ & $\begin{array}{c}\% \\
\text { Infected }\end{array}$ & $\begin{array}{c}\text { Total } \\
\text { no. }\end{array}$ & $\begin{array}{c}\% \\
\text { Infected }\end{array}$ & (n) & $\begin{array}{c}\% \\
\text { Infected }\end{array}$ \\
\hline \multicolumn{7}{|c|}{ Southwest } \\
\hline Nov 04 & 46 & 13 & 5 & 20 & 51 & 14 \\
\hline Jun 05 & 45 & 11 & 5 & 40 & 50 & 14 \\
\hline Aug 05 & 47 & 0 & 3 & 0 & 50 & 0 \\
\hline Oct 05 & 56 & 39 & 13 & 77 & 69 & 46 \\
\hline Nov 05 & 72 & 51 & 62 & 50 & 134 & 51 \\
\hline May 06 & 149 & 7 & 123 & 16 & 272 & 11 \\
\hline Jul 06 & 69 & 6 & 31 & 10 & 100 & 7 \\
\hline Oct 06 & 74 & 8 & 26 & 4 & 100 & 7 \\
\hline Nov 06 & 82 & 4 & 18 & 6 & 100 & 4 \\
\hline Mar 07 & 27 & 0 & 73 & 7 & 100 & 5 \\
\hline May 07 & 70 & 17 & 25 & 52 & 95 & 29 \\
\hline Jun 07 & 70 & 1 & 31 & 6 & 101 & 3 \\
\hline Aug 07 & 77 & 3 & 22 & 9 & 99 & 4 \\
\hline Oct 07 & 93 & 8 & 5 & 0 & 98 & 7 \\
\hline \multicolumn{7}{|l|}{ North } \\
\hline Nov 04 & 48 & 0 & 0 & - & 48 & 0 \\
\hline Apr 05 & 59 & 12 & 0 & - & 59 & 12 \\
\hline May 05 & 50 & 24 & 0 & - & 50 & 24 \\
\hline Aug 05 & 50 & 0 & 0 & - & 50 & 0 \\
\hline Nov 05 & 85 & 32 & 55 & 7 & 140 & 23 \\
\hline Feb 06 & 82 & 4 & 46 & 0 & 128 & 2 \\
\hline Mar 06 & 50 & 10 & 0 & - & 50 & 10 \\
\hline May 06 & 54 & 13 & 10 & 10 & 64 & 13 \\
\hline Jun 06 & 74 & 3 & 26 & 12 & 100 & 5 \\
\hline Jul 06 & 38 & 0 & 9 & 11 & 47 & 2 \\
\hline Aug 06 & 81 & 5 & 19 & 11 & 100 & 6 \\
\hline Oct 06 & 81 & 6 & 19 & 26 & 100 & 10 \\
\hline Dec 06 & 62 & 3 & 38 & 13 & 100 & 7 \\
\hline Feb 07 & 80 & 4 & 20 & 0 & 100 & 3 \\
\hline May 07 & 75 & 11 & 25 & 0 & 100 & 8 \\
\hline Aug 07 & 86 & 3 & 12 & 42 & 98 & 8 \\
\hline Sep 07 & 107 & 14 & 72 & 19 & 179 & 16 \\
\hline Oct 07 & 80 & 8 & 17 & 18 & 97 & 9 \\
\hline Dec 07 & 46 & 17 & 54 & 13 & 100 & 15 \\
\hline \multicolumn{7}{|c|}{ Southeast } \\
\hline Nov 04 & 178 & 6 & 36 & 3 & 214 & 6 \\
\hline Dec 04 & 50 & 4 & 0 & - & 50 & 4 \\
\hline Mar 05 & 25 & 24 & 22 & 5 & 47 & 15 \\
\hline Jun 05 & 57 & 5 & 30 & 7 & 87 & 6 \\
\hline Aug 05 & 58 & 0 & 2 & 0 & 60 & 0 \\
\hline Nov 05 & 50 & 12 & 0 & - & 50 & 12 \\
\hline Apr 06 & 136 & 13 & 129 & 19 & 265 & 15 \\
\hline Jul 06 & 59 & 2 & 12 & 25 & 71 & 6 \\
\hline Sep 06 & 59 & 3 & 14 & 14 & 73 & 5 \\
\hline Mar 07 & 84 & 6 & 73 & 15 & 157 & 10 \\
\hline May 07 & 44 & 14 & 12 & 33 & 56 & 18 \\
\hline Aug 07 & 68 & 9 & 7 & 14 & 75 & 9 \\
\hline Oct 07 & 74 & 8 & 4 & 25 & 78 & 9 \\
\hline
\end{tabular}




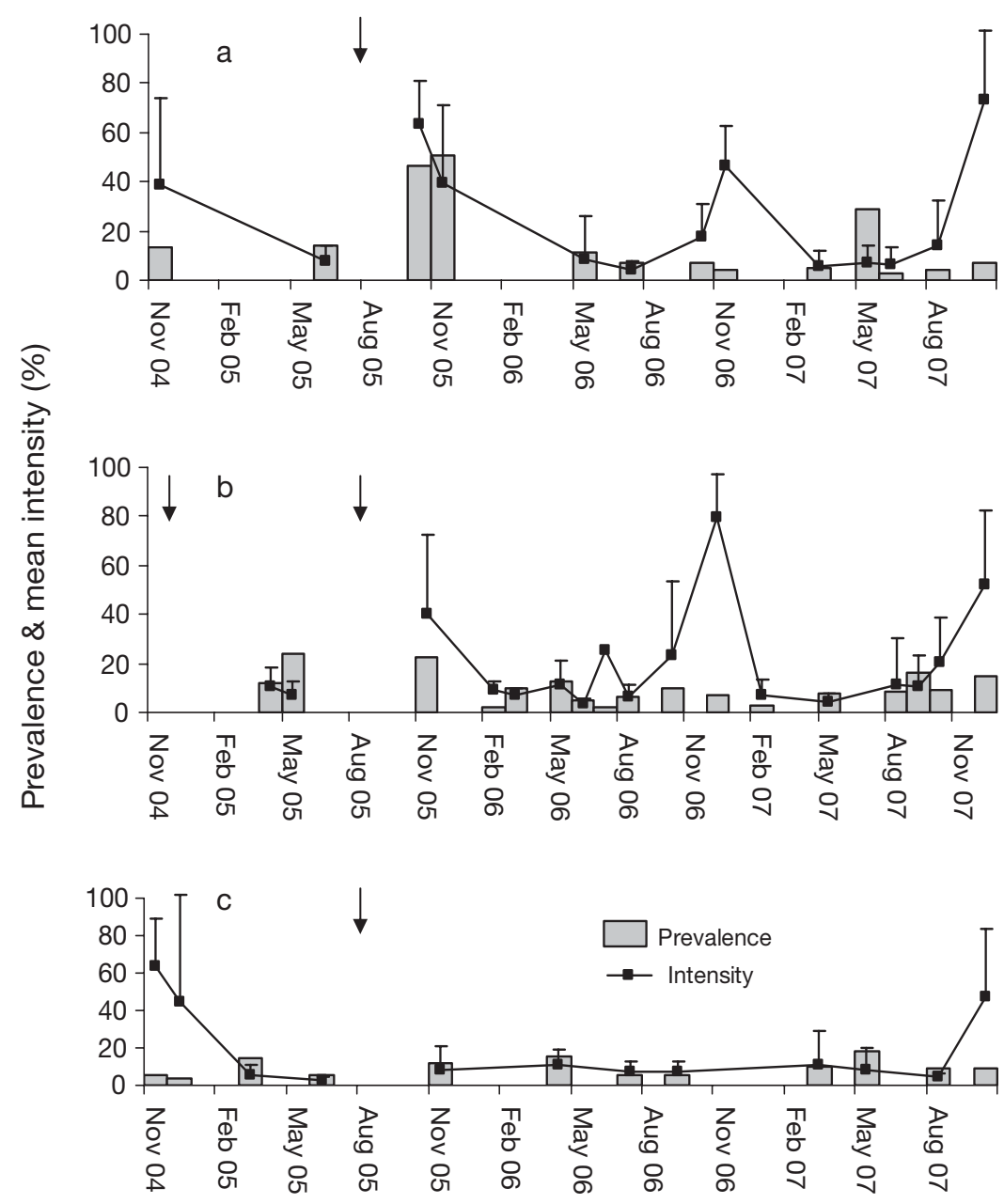

Fig. 3. Cancer pagurus. Seasonal variation in (grey bars) prevalence and mean (black square on line) intensity (+SD) of Hematodinium sp. infection from (a) southwest, (b) north and (c) southeast Ireland. Male and female samples pooled. Arrows: sampling when Hematodinium sp. was not encountered. Blank months: sampling did not occur plasmodia within infected individuals peaked in the Q4 cooling autumn phase each year (Fig. 5).

Infection intensity was examined in relation to different parasite morphologies. Of the 479 infected crabs, 311 were found to be infected with only the uninucleate trophont stage, while 166 contained varying amounts of plasmodia, with or without trophonts. Infection intensity was 96 and $85 \%$ for 2 ind. containing dinospores, but due to low sample numbers these were not compared to other stages. To ensure independence and homogeneity for statistical analysis, 166 infection intensity values were chosen at random from the 311 trophont-only infected crabs and were tested against the 166 plasmodial infections. Crabs infected with plasmodia had higher infection intensities than crabs infected with only trophonts (ANOVA, $\mathrm{p}<0.001)$. Infection intensity was significantly higher in females than males $(p<0.05)$.

\section{DISCUSSION}

This is the first report of Hematodinium sp. in Irish Cancer pagurus fisheries. Prior to 2004 the parasite had been either absent or undetected. As with a number of other important European commercial fisheries (La- in the north and $11 \%$ in the southwest in the late spring/early summer. Prevalence had increased to $29 \%$ in the southwest in 2007, 16\% in the north and $17 \%$ in the southeast in the summer/autumn months. Hematodinium sp. infections were not encountered in any area during August 2005 and no infections were encountered in November 2004 in the north.

Monthly mean seawater temperatures ranged between 8.8 and $16.8^{\circ} \mathrm{C}$ and were identical for the 3 geographic sampling locations. Infection intensities of Hematodinium sp. recorded within Q4 were significantly higher than those in the other 3 sampling quarters (Mood's median, $\mathrm{p}<0.001$ ), while Q2 was significantly lower than Q1 ( $p<0.05$ ) (Fig. 4). Significantly high infection intensities observed during Q4 each year corresponded with moderate and decreasing seawater temperatures (Fig. 5). The mean percentage of

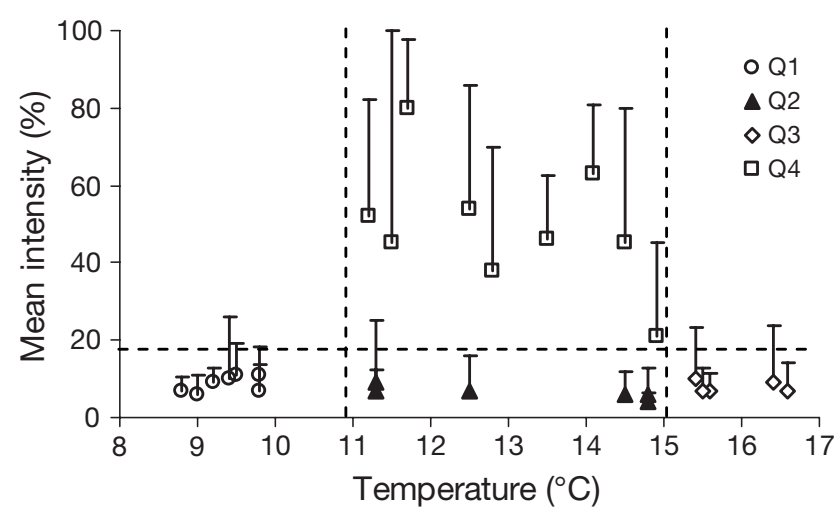

Fig. 4. Cancer pagurus. Mean intensity (+SD) of Hematodinium sp. infection in relation to seawater temperature. Samples are grouped by quarters of the year (Q1: January to April; Q2 May to June; Q3: July to September; Q4: October to December 


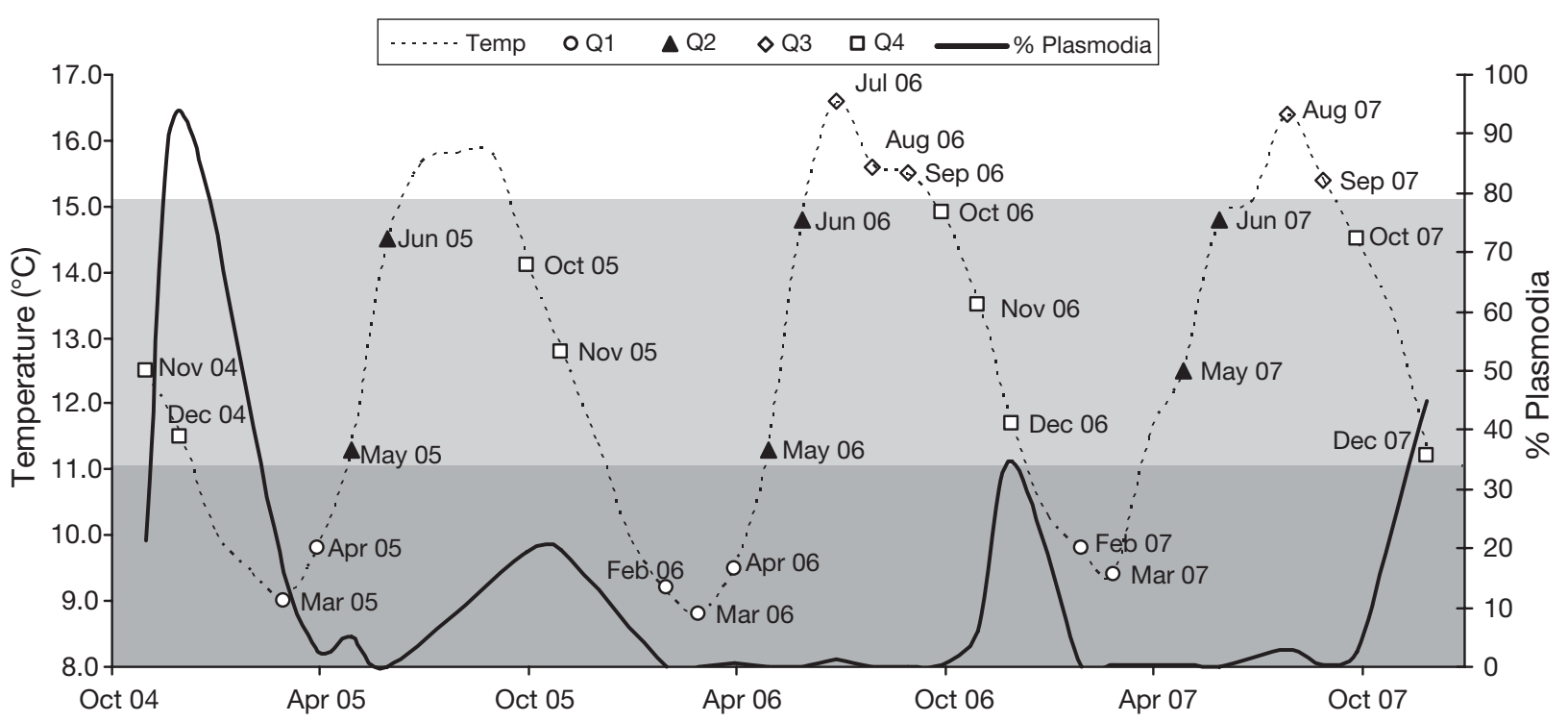

Fig. 5. Cancer pagurus. Seawater temperature profile, November 2004 to December 2007, and mean percentage of plasmodial cells present in Hematodinium sp.-infected individuals. Sampling dates are indicated by month and year and grouped by quarter (Q1: January to April; Q2: May to June; Q3: July to September; Q4: October to December). For clarity, associated errors are not shown, as data are intended to act as indicators of seasonal disease activity. Shaded bands: correspond to quarterly temperature groupings in Fig. 4 with Q2 and Q4 grouped together as they fall within the same temperature grouping

trouite et al. 1988, Wilhelm \& Boulo 1988, Field et al. 1992, Wilhelm \& Mialhe 1996, Briggs \& McAliskey 2002, Stentiford et al. 2002) there is concern it may significantly impact stock dynamics. Anecdotal industry reports suggest that PCD is a relatively new phenomenon in Irish waters, rather than being present but previously undetected. Despite extensive enquires, the condition had only been observed by one operator (J. O'Regan pers. comm.) in the southwest 2 to $3 \mathrm{yr}$ prior to the present study, and was unreported in other regions. As the occurrence of moribund and dead pink-shelled animals in fishing pots is obvious to the industry (Latrouite et al. 1988, Stentiford et al. 2002), it is unlikely that stakeholders in other areas fishing in an identical manner were failing to notice PCD. It is unclear whether a natural northern expansion in the geographic distribution of the parasite or artificial translocation has resulted in it reaching or being detected in stocks exploited by Irish vessels. It is possible the parasite was always present in low abundance or in conditions that did not lead to disease expression, and other undetermined factors have now led to its proliferation.

Although seasonality in peak prevalence of Hematodinium spp. has been reported for a number of crustacean fisheries worldwide (Newman \& Johnson 1975, Meyers et al. 1990, Eaton et al. 1991, Field et al. 1992, 1998, Love et al. 1993, Messick 1994, Stentiford et al. 2001, Sheppard et al. 2003) and has often been used to discuss potential disease impact on stocks, it was not predictable in Irish Cancer pagurus stocks despite being present at all times throughout the year. It was high infection intensity, not peak prevalence, which coincided with the occurrence of highly degraded specimens; therefore, knowledge of intensity is much more useful for predicting the biological and economic impacts of PCD. Presently in Ireland, management advice to the industry relates only to pink-shelled crabs by discouraging: (1) discarding of late-stage infected individuals back into the water while at sea, (2) leaving carcasses and terminally infected individuals in pots as attractants for the next fishing period, and/or (3) retention of moribund, poor quality individuals as bait in other fisheries and/or areas. Although Meyers et al. $(1987,1990)$ suggested the transportation of infected individuals to onshore waste facilities may be effective in reducing the potential spread of the disease, in the present study, macroscopic signs of infection only occurred during a discrete period and consistently underscored prevalence, indicating that only a proportion of infected individuals within a population can be managed during a restricted time. With further refinement, scientifically derived infection intensity data could be incorporated into stock assessment estimates and subsequent input (e.g. fishing effort) and output (e.g. quota) management advice. Diseaserelated contributions to natural mortality are not currently factored into assessment methods for this species.

Although the intention was to sample a minimum of 100 ind. on a quarterly basis, closed fishing seasons and sporadic availability of samples due to bad 
weather resulted in some discontinuity. The apparent variability in prevalence may have been an artefact of relatively small sample sizes, but as crabs were taken from standardised locations and processed in an identical manner, this seems unlikely. However, previous studies have shown the relevant stocks to be highly mobile (Tully et al. 2006), showing strong directional migration patterns. Crab movements into and out of localised sampling areas within each of the fisheries could account for much of the variability in prevalence, as the potential for exposure to Hematodinium spp. infection can vary geographically (Shields et al. 2005).

A parasitic marine dinoflagellate life cycle involves an infective agent (dinospore), a growth stage (trophonts and plasmodia) and a sporogenic reproductive phase that generates large numbers of dinospores (Coats 1999). We suggest that the high infection intensity Q4 season corresponds to the main growth phase preceding the production of dinospores, as vast numbers of trophonts and plasmodia were observed only during this period, as were macroscopic signs of infection and dinospores. Seawater temperature, or processes and/or parameters linked to it (e.g. moulting, mating, metabolism, condition), was a determining factor in triggering stages in the reproductive lifecycle of the parasite. This theory is supported by industry reports of late stage, terminally infected or dead Cancer pagurus in pots only during November and December, with these mortalities explaining the lower prevalence and absence of heavily infected crabs observed in spring. While the peak in mean percentage of plasmodia appeared less pronounced in 2005, poor weather conditions prevented sample collection that December, which appeared to correspond to the peak in the other years. Similar to the present study, Latrouite et al. (1988) reported the presence of Hematodinium sp. in French brown crabs in all months examined with a marked increase in the number of pink crabs and mortalities during the winter months. Stentiford et al. (2002) reported similar seasonality in peak infection.

Transmission of Hematodinium spp. in other host species has long been associated with moulting (Meyers et al. 1987, 1990, Eaton et al. 1991, Field et al. 1992, Dawe 2002, Shields et al. 2005, 2007). The main moulting period for brown crabs in Irish fisheries occurs from September to December (Tully et al. 2006), coinciding with high infection intensities observed in Q4 in the present study. The hypothesis that crabs contract Hematodinium sp. infections during ecdysis may account for the relatively high prevalence of low level infections in the spring. We postulate that the warmer months in Q2 and Q3 allow for the growth of the early infectious stage, and the cooling associated with Q4 initiates division of cells prior to the production of dinospores, eventually leading to death of the host. This would suggest a lifecycle of approximately 12 mo for the parasite in this host. Tagging and growth studies in Ireland have shown decreasing moult frequency with increasing size of brown crab (Tully et al. 2006). If infection is linked directly to or increased by ecdysis, then this may afford large crabs or those moulting early in the season a temporary refuge from infection and account for the high prevalence observed in the small size classes in this study. As standard fishing pots have a mesh panelling that allows escapement of individuals $<80 \mathrm{~mm} \mathrm{CW}$, smaller individuals were not fully represented, rendering prevalence data 'apparent' rather than 'total'. Consequently, there are concerns as to disease impact on pre-fishery recruits in nursery areas that are known to overlap or are directly adjacent (Tully et al. 2006) to the main fishing areas. Shields et al. (2005) highlighted the potential for significant losses from both the fished and pre-recruit components of stocks of snow crabs Chionoecetes opilio, specifying that disease impact on recruitment is difficult to quantify without carefully designed, directed surveys.

The presence of Hematodinium sp. in Ireland has raised concerns not only due to its potential biological impact on Cancer pagurus stocks, but also due to the risk of damaging consumer confidence if deteriorated products reach consumers. Although the majority of infected animals screened during the present study showed no visible signs of disease or deterioration, the observed pattern of significant increases in infection intensity and the appearance of late-stage infections in Q4 coincided with maximum economic unit value for Irish C. pagurus. Demand for live crab products in continental Europe peak just prior to and during the Christmas festival period, and market prices can as much as quadruple in response. As live export duration between capture and consumption can exceed $20 \mathrm{~d}$ (Tully et al. 2006), there is potential that individuals with infections insufficiently progressed to be macroscopically identifiable at capture may already have internal tissue degradation or develop it prior to reaching the consumer. Additionally, infected C. pagurus and other crab species have been reported to suffer and die more readily during captivity than uninfected conspecifics (Meyers et al. 1987, Stentiford et al. 2002). Stakeholders involved in live export must be made aware of the risks associated with medium-term storage during this period in the absence of data relating to disease progression.

Acknowledgements. The project was funded by the Irish Government and part-financed by the EU under the National Development Plan 2000-2006 through the programme for Innovation and Sustainability in the Fisheries Sector, administered by the Irish Sea Fisheries Board (Bord Iascaigh Mhara). 
Authors gratefully acknowledge the skippers and crews of all the fishing vessels that provided samples throughout this study and the Marine Institute of Ireland for providing sea temperature data. The authors are grateful to the anonymous reviewers whose suggestions improved this manuscript.

\section{LITERATURE CITED}

Appleton PL, Vickerman K (1998) In vitro cultivation and development cycle in culture of a parasitic dinoflagellate (Hematodinium sp.) associated with mortality of the Norway lobster (Nephrops norvegicus) in British waters. Parasitology 116:115-130

Briggs RP, McAliskey M (2002) The prevalence of Hematodinium in Nephrops norvegicus from the western Irish Sea. J Mar Biol Assoc UK 82:427-433

Bush AO, Lafferty KD, Lotz JM, Shostak AW (1997) Parasitology meets ecology in its own terms: Margolis et al. revisited. J Parasitol 83:575-583

Coats DW (1999) Parasitic lifestyles of marine dinoflagellates. J Eukaryot Microbiol 46:402-409

Dawe E (2002) Trends in the prevalence of bitter crab disease caused by Hematodiniun sp. in snow crab (Chionoecetes opilio) throughout the Newfoundland and Labrador continental shelf. In: Paul AJ, Dawe EG, Elner R, Jamieson GS and others (eds) Crabs in cold water regions: biology, management, and economics. Alaska Sea Grant Report AK-SG-02-01, Alaska Sea Grant Program, University of Alaska, Fairbanks, AK, p 385-400

Eaton WD, Love DC, Botelho C, Meyers TR, Imamura K, Koeneman T (1991) Preliminary results on the seasonality and life cycle of the parasitic dinoflagellate causing bitter crab disease in Alaskan Tanner crabs (Chionoecetes bairdi). J Invertebr Pathol 57:426-434

Field RH, Chapman CJ, Taylor AC, Neil DM, Vickerman K (1992) Infection of the Norway lobster Nephrops norvegicus by a Hematodinium-like species of dinoflagellate on the west coast of Scotland. Dis Aquat Org 13:1-15

Field RH, Hills JM, Atkinson RJA, Magill S, Shanks AM (1998) Distribution and seasonal prevalence of Hematodinium sp. infection of the Norway lobster (Nephrops norvegicus) around the west coast of Scotland. ICES J Mar Sci 55:846-858

Humason GL (1979) Animal tissue techniques, 4th edn. WH Freeman, San Francisco, CA

Latrouite D, Morizur Y, Noël P, Chagot D, Wilhelm G (1988) Mortalité du tourteau Cancer pagurus provoquée par le dinoflagellate parasite: Hematodinium sp. Cons Int Explor Mer, CM 1988/K:32

Love DC, Rice SD, Moles DA, Eaton WD (1993) Seasonal prevalence and intensity of bitter crab dinoflagellate infection and host mortality in Alaskan Tanner crabs Chionoecetes bairdi from Auke Bay, Alaska, USA. Dis Aquat Org 15:1-7

Messick GA (1994) Hematodinium perezi infections in adult and juvenile blue crabs Callinectes sapidus from coastal bays of Maryland and Virginia, USA. Dis Aquat Org 19: $77-82$

Meyers TR, Koeneman TM, Bothelho C, Short S (1987) Bitter crab disease: a fatal dinoflagellate infection and marketing problem for Alaskan Tanner crabs Chionoecetes bairdii. Dis Aquat Org 3:195-216

> Meyers TR, Botelho C, Koeneman TM, Short S, Imamura K (1990) Distribution of bitter crab dinoflagellate syndrome in southeast Alaskan Tanner crabs, Chionoecetes bairdi. Dis Aquat Org 9:37-43

> Newman MW, Johnson CA (1975) A disease of blue crabs (Callinectes sapidus) caused by a parasitic dinoflagellate, Hematodinium sp. J Parasitol 61:554-557

Sheppard M, Walker A, Frischer ME, Lee RF (2003) Histopathology and prevalence of the parasitic dinoflagellate Hematodinium sp. in crabs (Callinectes sapidus, Callinectes similis, Neopanope sayi, Libinia emarginata, Menippe mercenaria) from a Georgia estuary. J Shellfish Res 22:873-880

> Shields JD, Taylor DM, Sutton SG, O'Keefe PO, Collins PW, Ings DW, Pardy AL (2005) Epizootiology of bitter crab disease (Hematodinium sp.) in snow crabs, Chionoecetes opilio, from Newfoundland, Canada. Dis Aquat Org 64: 253-264

Shields JD, Taylor DM, O'Keefe PG, Colbourne E, Hynick E (2007) Epidemiological determinants in outbreaks of bitter crab disease (Hematodinium sp.) in snow crabs, Chionoecetes opilio from Conception Bay, Newfoundland, Canada. Dis Aquat Org 77:61-72

Stentiford GD, Shields JD (2005) A review of the parasitic dinoflagellates Hematodinium species and Hematodinium-like infections in marine crustaceans. Dis Aquat Org $66: 47-70$

Stentiford GD, Neil DM, Atkinson RJA (2001) The relationship of Hematodinium infection prevalence in a Scottish Nephrops norvegicus population to seasonality, moulting and sex. ICES J Mar Sci 58:814-823

Stentiford GD, Green M, Bateman K, Small HJ, Neil DM, Feist SW (2002) Infection by a Hematodinium-like parasitic dinoflagellate causes pink crab disease (PCD) in the edible crab Cancer pagurus. J Invertebr Pathol 79:179-191

Taylor DM, Khan RA (1995) Observations on the occurrence of Hematodinium sp. (Dinoflagellata: Syndinidae): the causative agent of bitter crab disease in the Newfoundland snow crab (Chionoecetes opilio). J Invertebr Pathol 65:283-288

Tully O, Robinson M, O'Keeffe E, Cosgrove R, Doyle O, Lehane B (2006) The brown crab (Cancer pagurus L.) fishery: analysis of the resource in 2004-2005. Fisheries Research Series No. 4, Bord Iascaigh Mhara (Irish Sea Fisheries Board), Dun Laoghaire

Wilhelm G, Boulo V (1988) Infection de l'étrille Liocarcinus puber (L.) par un dinoflagelle parasite: Hematodinium sp. Cons Int Explor Mer, Ser CM, K:41:1-10

- Wilhelm G, Mialhe E (1996) Dinoflagellate infection associated with the decline of Necora puber crab populations in France. Dis Aquat Org 26:213-219

Submitted: July 24, 2008; Accepted: November 10, 2008 Proofs received from author(s): January 21, 2009
Editorial responsibility: Grant Stentiford, Weymouth, UK 